\title{
Enzymes as a Tool to Investigate Biofilm Structures and to Control Bio films
}

\author{
Joo Sung Kim¹,2* and Joo Young Lee ${ }^{3}$ \\ ${ }^{1}$ Division of Food Safety, Korea Food Research Institute, Republic of Korea \\ ${ }^{2}$ Department of Food Biotechnology, Korea University of Science and Technology, Republic of Korea \\ ${ }^{3}$ Food Analysis Center, Korea Food Research Institute, Republic of Korea
}

Submission: February 6, 2017; Published: February 7, 2017

*Corresponding author: Joo Sung Kim, Korea Food Research Institute, 1201-62, Anyangpangyo-ro, Bundang-gu, Seongnam-si, Gyeonggi-Do, Republic of Korea, Tel: 82-31-780-9266; Fax: 82-31-709-9876; Email: jskim@kfri.re.kr

\section{Abstract}

Biofilm is one of the important part of life cycle in bacteria and a potential source of contamination. Although biofilm has an important aspect due to its nature in resistance to environmental stresses, its structures are variable depending on bacterial species and the knowledge of biofilm structures still remains poorly understood. Because enzymes are generally highly specific for substrates, those enzymes can be used to study biofilm structures or to control biofilms.

Keywords: Biofilm; Enzyme; Structure; Control

\section{Opinion}

Bacteria often form biofilms in their lives on both abiotic and biotic surfaces and the biofilms can often affect our human life negatively because they are hard to remove and tend to be resistant to environmental stress conditions including sanitizers and antimicrobials. The pathogenic bacterial cells surviving the stressful conditions in the form of biofilm can be persistent in the environment and cause human infections. Thus, the understanding of biofilm structures is certainly necessary to eventually find a way to easily remove the biofilms or inhibit the biofilm formation.

In many bacterial species, the biofilm is protected in the matrix of extracellular polymeric substances usually composed of proteins, carbohydrates, lipids, and extracellular DNA. Such a structure makes it easy to communicate among the cells through quorum sensing in protected environment. However, the detailed components or structures are not well understood in many times and warrants further studies. Enzymes are usually highly specific for substrates to degrade, and can be potentially used as a useful tool to study biofilm structures. Such an identified substrate playing a pivotal role in the biofilm structures can be a promising target to prevent biofilm formation or degrade the pre-formed biofilms. Several studies have already demonstrated that substrate-degrading enzymes can be a useful tool to investigate the biofilm structures or the mechanism of biofilm formation by observing the reduction of biofilm mass or the inhibition of biofilm formation after enzyme treatments [1-4]. For example, extracellular DNA in bacterial biofilms has become a promising target for biofilm control through observing the effect of DNase in degrading biofilms. In addition, alpha-amylase was able to inhibit the biofilm formation or to reduce the preformed biofilms of Staphylococcus aureus isolates, suggesting that carbohydrates play an important role in the integrity of $\mathrm{S}$. aureus biofilms [1].

Such an enzyme treatment can be also an useful tool to control biofilms. Enzyme treatment can degrade pre-formed biofilms or inhibit the biofilm formation. Also, disintegration of biofilm structures by enzymes can make it easy for antimicrobials including antibiotics to penetrate the biofilm structures and inactivate the bacterial cells. Indeed, previous studies demonstrated the increased inactivation of pathogenic bacterial cells in biofilms by antibiotics in the presence of enzymes such as DNase I [3]. Even though the cost can be problematic, the ecofriendly nature makes enzyme a promising method to control biofilms in our environments. In addition, such a target-specific enzyme can be applied in many different ways such as antibiofilm coatings [5]. 
Therefore, enzymes can be used as a useful tool to study biofilm structures and control biofilms.

\section{References}

1. Craigen B, Dashiff A, Kadouri DE (2011) The use of commercially available alpha-amylase compounds to inhibit and remove Staphylococcus aureus biofilms. Open Microbiol J 5: 21-31.

2. Okshevsky M, Regina VR, Meyer RL (2015) Extracellular DNA as a target for biofilm control. Curr Opin Biotechnol 33: 73-80.
3. Tetz G, Artemenko NK, Tetz VV (2009) Effect of DNase and antibiotics on biofilm characteristics. Antimicrob Agents Chemother 53(3): 12041209.

4. Whitchurch CB, Tolker-Nielsen T, Ragas PC, Mattick JS (2002) Extracellular DNA required for bacterial biofilm formation. Science 295(5559): 1487.

5. Swartjes JJTM, Das T, Sharifi S, Subbiahdoss G, Sharma PK, et al. (2013) A functional DNase I coating to prevent adhesion of bacteria and the formation of biofilm. Adv Funct Mater 23(22): 2843-2849.

\section{Your next submission with Juniper Publishers will reach you the below assets}

- Quality Editorial service

- Swift Peer Review

- Reprints availability

- E-prints Service

- Manuscript Podcast for convenient understanding

- Global attainment for your research

- Manuscript accessibility in different formats ( Pdf, E-pub, Full Text, Audio)

- Unceasing customer service

Track the below URL for one-step submission https://juniperpublishers.com/online-submission.php 